DOI https://doi.org/10.30525/978-9934-26-113-8-9

\title{
ЕНЗИМИ СЕЧІ ТА ПРОГНОЗУВАННЯ ЕФЕКТИВНОСТІ ЕНДОСКОПІЧНОГО ЛІКУВАННЯ ДІТЕЙ 3 ВРОДЖЕНИМ МІХУРОВО-СЕЧОВІДНИМ РЕФЛЮКСОМ
}

\author{
Нікуліна Г. Г. \\ доктор біологічних наук, професор, \\ завідувач лабораторії біохімії \\ ДУ «Інститут урологї Національної академії медичних наук України»
}

\section{Петербургський В. Ф.}

доктор медичних наук, завідувач відділу дитячої урології

ДУ «Інститут урологї̈ Наџіональної академії медичних наук України»

Мигаль Л. Я.

кандидат медичних наук, старший науковий співробітник лабораторії біохімії ДУ «Інститут урологї̈ Наџіональної академії медичних наук України»

Каліщук О. А.

кандидат медичних наук, старший науковий співробітник відділу дитячої урології ДУ «Інститут урологї̈ Національної академії медичних наук України»

\section{Сербіна I. Є.}

науковий співробітник лабораторії біохімії

ДУ «Інститут урологї̈ Національної академії медичних наук України» м. Київ, Україна

Міхурово-сечовідний рефлюкс (МСР) - ретроградне надходження сечі із сечового міхура у напрямку нирок, займає провідне місце в структурі дитячої урологічної патології та $\epsilon$ однією 3 найбільш розповсюджених вроджених вад сечовидільної системи у дітей [1, с. 198]. Наявність МСР сприяє поширенню інфекції з сечового міхура у верхні сечові шляхи та нирки. Несвоєчасні діагностика та патогенетичне лікування цієї патології призводять до виникнення пієлонефриту та його грізних ускладнень - нефрогенної гіпертензії, 
рефлюкс-нефропатії, вторинно-зморщеної нирки та ниркової недостатності [2, с. 107-110]. Іноді негативний вплив зворотного потоку сечі на функцію нирок здійснюється безсимптомно, чітко виявляючись лише у підлітковому віці, що свідчить про незадовільні результати діагностики, незадовільне відповідно прогнозування подальшого перебігу хвороби та іiі лікування та про можливість прогресування у цих хворих патологічного процесу [2, с. 107-110].

Нирки, як відомо, є найбільшим джерелом ензимів, які виявляються у сечі, [3, с. 9-10]. Ось чому визначення активності ферментів сечі, враховуючи реноспецифічність деяких 3 них, таких як канальцевий лізосомний фермент $\mathrm{N}$-ацетил- $\beta$-D-глюкозамінідаза (НАГ) та іiі термостабільний ізофермент $\mathrm{N}$-ацетил- $\beta$-D-глюкозамінідаза В (НАГ В), який, як відомо, має більш виражені реноспецифічні властивості порівняно із загальною активністю НАГ [3, с. 10-11; 4, с. 40 5, с. 219], $\epsilon$ найбільш інформативними методами, які об'єктивно відбивають стан гіпоксично-ішемічних порушень у тубулярному епітелії паренхіми нирки та характеризують таким чином його функціональний стан $[3$, с. $10-14 ; 4$, с. $37-44 ; 5$, с. $219 ; 6$, c. $84-89 ; .7$, с. 66,$70 ; 8$, с. $57-71]$.

Мета роботи - оцінити можливість визначення рівнів активності НАГ та НАГ В сечі як ензимологічних маркерів прогнозування ефективності ендоскопічного лікування дітей з вродженим МСР.

Обстежено 51 дитину (39 дівчаток та 12 хлопчиків) віком від 1 року до 15 років з верифікованим діагнозом - однобічний вроджений МСР (виключення впливу протилежної нирки на показники ферментативної активності у сечі з сечового міхура) та 25 практично здорових дітей того ж віку та статі (контроль). Функція нирок хворих дітей на момент дослідження збережена, атак гострого або загострення хронічного пієлонефриту не спостерігалось.

Сечу для аналізу отримували під час фізіологічного сечовипускання. Активність ензимів у сечі визначали до ендоскопічного лікування [9, с. 1192-1195] та через 6 місяців після. Активність НАГ та НАГ В сечі розраховували у мкмолях пара-нітрофенолу, що утворився протягом 1 години, із розрахунку на 1 ммоль креатиніну сечі, який визначали за кольоровою реакцією Яффе (мкмоль/год/ммоль креатиніну).

Розраховували середню арифметичну величину та ії похибку $(\mathrm{M} \pm \mathrm{m})$.

Статистичну вірогідність результатів досліджень оцінювали за tкритерієм Ст'юдента за допомогою програмного забезпечення Microsoft Excel, порогом значущості відмінностей вважали $\mathrm{p}<0,05$.

Встановлено, що у сечі здорових дітей загальна активність НАГ дорівнює 11,64 $\pm 0,72$ мкмоль/год/ммоль креатиніну, $\sigma=3,61$, активність ii термостабільного ізоферменту НАГ В дорівнюе $1,56 \pm 0,096$, $\sigma=0,48$. Межі загальної активності НАГ та активності НАГ 
В у сечі здорових дітей розраховували за формулою $\mathrm{M} \pm 1,5 \sigma$. Для загальної активності НАГ сечі це інтервал від 6,2 до 17.1 мкмоль/год/ммоль креатиніну, для активності НАГ В сечі - інтервал від 0,8 до 2,3 мкмоль/год/ммоль креатиніну.

За результатами індивідуального ретроспективного аналізу рівнів загальної активності НАГ та іiі ізоформи НАГ В у сечі дітей з МСР залежно від ефективності ендоскопічного лікування через 6 місяців після його завершення на підставі особливостей змін рівнів сечової активності обох ензимів, хворих поділили на наступні групи: група 1 - із загальною активністю НАГ та НАГ В сечі у межах нормальних величин $(\mathrm{n}=12)$; група 2 - із загальною активністю НАГ сечі у межах нормальних величин та активністю НАГ В сечі вищою за верхню межу ії нормальних величин ( $\mathrm{n}=34)$; група 3 - із загальною активністю НАГ та НАГ В сечі вищою за верхню межу їх нормальних величин $(\mathrm{n}=5)$; група 4 - група контролю $(\mathrm{n}=25)$.

Отримані результати засвідчили, що рівні загальної активності НАГ з 1-ї групи як до лікування, так і після лікування практично не відрізняються від аналогічних показників 2-ї групи та групи контролю та достовірно нижчі за аналогічний показник із групи $3(\mathrm{p}<0,001)$. У той же час рівні активності НАГ В у 2-й групі як до лікування, так і після лікування достовірно вищі як за аналогічний показник із групи 1, так і за аналогічний показник із групи контролю $(\mathrm{p}<0,001)$ та практично не відрізняються від аналогічного показника 3-ї групи, що підтверджує правильність нашого підходу до встановлення меж розподілу між здоровими та хворими дітьми.

Також встановлено, що, незважаючи на деякі коливання середніх показників, рівні активності обох ензимів через 6 місяців після лікування у кожній із груп практично не змінилися порівняно з вихідними даними.

Отже, якщо загальна активність НАГ у долікувальному періоді визначається у інтервалі від 6,2 до 17,1 мкмоль/год/ммоль креатиніну, а активність НАГ В - у інтервалі від 0,8 до 2,3 мкмоль/год/ммоль креатиніну, тобто відповідають контрольним значенням, що вказує на неушкодженість клітинних та лізосомних мембран та відсутність порушення функціонального стану канальцевого нефротелію, то прогнозують позитивну ефективність ендоскопічного лікування через 6 місяців після втручання; якщо до початку ендоскопічного лікування (вихідні дані) загальна активність НАГ відповідає контрольним значенням, a активність НАГ В у цих же пацієнтів $\epsilon$ стало вищою за 2,3 мкмоль/год/ммоль креатиніну, що свідчить про дисфункцію канальцевого апарата паренхіми нирки та вказує на необхідність виділення цих хворих у групу ризику розвитку можливих ускладнень, то прогнозують часткову ефективність реконструктивного лікування через 36 
6 місяців після втручання; якщо до початку ендоскопічного лікування загальна активність НАГ є стало вищою за 17,1 мкмоль/год/ммоль креатиніну, а активність НАГ В - за 2,3 мкмоль/год/ммоль креатиніну, що вказує на порушення функціонального стану паренхіми нирки на момент дослідження, то прогнозують неефективність реконструктивного лікування через 6 місяців після втручання в плані відновлення функціонального стану канальцевого апарата паренхіми нирки.

Таким чином, незважаючи на позитивні результати ендоскопічного лікування МСР у дітей (за даними відновлення уродинаміки), хворим із групи 2 та особливо пацієнтам із групи 3 у післялікувальному періоді необхідно своєчасно призначати адекватну корегуючу мембрано- та ренопротекторну терапію 3 метою не допустити в подальшому розвитку та прогресуванню у них грізних ускладнень. А визначення рівнів активності загальної НАГ та піi ізоферменту НАГ В сечі як ензимологічних маркерів прогнозування ефективності ендоскопічного лікування дітей з вродженим МСР є доцільним.

\section{Література:}

1. Зоркин С. Н., Хворостов И. Н., Смирнов И. Е. и др. Патогенетические основы формирования и принципы лечения обструктивных уропатий у детей. Вісник Віннищького Наџіонального університету. 2007. T. 11 (1/1). С. 198-204.

2. Морозова О. Л., Морозов Д. А., Лакомова Д. Ю. и др. Рефлюкснефропатия у детей: ранняя диагностика и мониторинг. Урология. 2017. № 4. C. 107-112.

3. Бабаева Н. И., Липицкая И. Я., Творогова М .Г. и др. Диагностическое значение исследования активности $\mathrm{N}$-ацетил- $\beta$ D- глюкозаминидазы в моче (обзор литературы). Лабораторное дело. 1991. № 1. C. 9-16.

4. Мельник A. А. Диагностическая роль N-ацетил-бета-Dглюкозаминидазы как раннего маркера повреждения почек. Нирки. 2016. № 4 (18). С. 37-47.

5. Mygal L. Ya., Nikulina G. G., Peterburgsky V.F. et al. Urinary enzymes as markers in diagnostics of the concealed dysfunctioning of tubular nephrothelium in children with congenital vesico-ureteric reflux. Медична та клінічна хімія: науковий журнал. (Матеріали ХІІ Украӥнського. біохімічного конгресу. м. Тернопіль, 30.09 - 04.10. 2019): 2019. т. 21. № 3 (80). (додаток 1). С. 219.

6. Mohkam M., Ghafari A. The Role of Urinary N-acetyl-betaglucosaminidase in Diagnosis of Kidney Diseases. Journal of Pediatric Nephrology. 2015. Vol. 3 Issue 3. P. 84-91. 
7. Лавренчук О. В. Багдасарова І. В., Король Л. В., Мигаль Л. Я. Біохімічні предиктори розвитку хронічної хвороби нирок у дітей, реконвалесцентів гострого пошкодження нирок I.В. Запорожский медииинский журнал. 2021. Том 23. № 1 (124). С. 65-71.

8. Lopez-Giacoman S., Madero M. Biomarkers in chronic kidney disease, from kidney function to kidney damage. World Journal of Nephrology. 2015. Vol. 4. Issue 1. P. 57-73.

9. Watters S. T., Sung J., Skoog S. J. Endoscopic treatment for vesicoureteral reflux: how important is technique? Journal of Pediatric Urology. 2013. Vol. 9 (6 Pt B). P. 1192-1197.

DOI https://doi.org/10.30525/978-9934-26-113-8-10

\title{
ЧИННИКИ РИЗИКУ РОЗВИТКУ ПОСТМЕНОПАУЗАЛЬНОГО ОСТЕОПОРОЗУ
}

\author{
Пилипчук I. C. \\ кандидат медичних наук, \\ дочент кафедри акушерства та гінекологіі \\ Львівський національний медичний університет \\ імені Данила Галищького \\ Флуд В. В. \\ кандидат медичних наук, \\ асистент кафедри акушерства та гінекологї \\ Львівський національний медичний університет \\ імені Данила Галицького \\ Петришин 3. Я. \\ асистент кафедри акушерства та гінекології \\ Львівський національний медичний університет \\ імені Данила Галиџького \\ м. Львів, Украӥна
}

Остеопороз (лат. osteoporosis) - це метаболічне захворювання скелета, що характеризується прогресуючим зниженням кісткової маси в одиниці об єму кістки відносно нормального показника в осіб відповідної статі та віку, порушенням мікроархітектоніки кісткової тканини зі збільшенням крихкості та ризику їх переломів від мінімальної травми 